\title{
Effects of School Shooting on School Climate: A Review of Social Bond Theory
}

\author{
Okulda Silahlı Saldırının Okul Iklimi Üzerindeki Etkileri: Sosyal Bağ Teorisinin Gözden \\ Geçirilmesi
}

\author{
(D) Ezgi Ildırım Özcan Asst. Prof. ${ }^{1}$, (D) Ayhan Erbay Asst. Prof. ${ }^{2}$ \\ 1istinye University Faculty of Arts and Sciences, Department of Psychology, İstanbul, Turkey \\ ${ }^{2}$ Haliç University Faculty of Arts and Sciences, Department of Psychology, İstanbul, Turkey
}

\section{ABSTRACT}

It has been aimed to examine the relationship between how school shooting disrupts school climate and what are the consequences of this situation. Although school shooting is among the primary problems of society from time to time, it is in reality an issue to which society pays attention only when such an event breaks out. School shooting, on the other hand, has a devastating impact on students, teachers, and other school staff, as well as deeply shaking the school climate. At this point, Social Bond Theory has been used as a theoretical framework to understand the effects of school shooting. The theory proposes that when school shooting occurs students precisely de-attach from school, therefore from the society. They do not commit to social norms and rules, and eventually lose their faith in society as a result of the school shooting. In this study, the effects of school shooting on the school climate were discussed and some prevention suggestions were developed.

Keywords: School shooting, Social Bond Theory, school climate

\section{Öz}

Okulda silahlı saldırı, zaman zaman toplumun temel sorunları arasında yer alsa da, gerçekte böyle bir olay çıktığında toplumun dikkat ettiği bir konudur. Öte yandan okulda ateș etme, öğrenciler, öğretmenler ve diğer okul personeli üzerinde yıkıcı bir etkiye sahip olduğu gibi okul iklimini derinden sarsmaktadır. Bu noktada Sosyal Bağ Teorisi, okulda silahlı saldırıların etkilerini anlamak için teorik bir çerçeve olarak kullanılmıştır. Teori, okulda silahlı saldıı gerçekleștiğinde özellikle öğrencilerin okuldan, dolayısıyla toplumdan bağlarını kopardı̆̆ını öne sürer. Öğrenciler, sosyal normlara ve kurallara bağlı kalmazlar ve sonunda topluma olan inançlarını kaybederler. Bu çalıșmada, okulda yașanan silahlı saldırıların okul iklimini nasıl etkilediği tartışılmış ve bazı önleme önerileri geliștirilmiștir.

Anahtar Kelimeler: Okulda silahlı saldırı, Sosyal Bağ Teorisi, okul iklimi

\section{INTRODUCTION}

School shootings are studied by researchers from various disciplines in order to understand this phenomenon and to take measures to prevent it. Researchers especially focus on reasons and dynamics of school shootings (1). While various disciplines focus on different aspects of this criminal behavior, a comprehensive and interdisciplinary viewpoint seems to be necessary for a wider comprehension. As Böckler, Seeger et al. (2) stated, it is better for researchers to focus on violence affirming settings. Violence in the school has many sources, 
as do risky behaviors that can precede school violence, like bringing guns to school. The research to understand school violence generally focused on implicit reasons such as parentchild relationship, substance use, having a history of violence, and bullying $(3,4)$. According to recent research, children and adolescents bring guns to school for a number of reasons, including fear of victimization and peer pressure (5). However, in particular, offenders have generally been looked at from a mental health standpoint (6). A majority of this literature has pointed depression, anger, anxiety, and fear as risk factors for both school violence and risky behaviors like gun carrying (7-9). Undoubtedly, all kinds of actions that occur in the school somehow affect the functioning of the school, the behavior of the students and the school-student symbiosis. Shooting at school or actions using any weapon damage this symbiosis. Although there are not many studies examining the effects of school shootings, it is known that violent acts have impacts on school climate.

School climate is a complex construct used to describe characteristics of interactions among adults and students at school (10). It includes norms, values and expectations related to school yet it is not limited to these factors. Students' and school personnel's experiences of school life, interpersonal relationships, organizational structure and learning practices are also determinable in school climate. Studies on this field revealed that school climate is critical for both students' and teachers' experiences. School climate is often measured using student perceptions of how they get along with each other and are treated by school staff (10-12). One of the most frequently used markers of school climate is students' perceptions of whether teachers (and other school staff) care about them and treat them fairly (10). Student perceptions of supportive school climate have been linked to student adjustment, commitment to learning, and academic achievement (11), as well as school safety (12).

School climate has impacts on not only students' academic achievement but also on their behavior. From a psychological view, several theories like Bronfenbrenner's ecological model (13) and attachment theory (14) emphasize on the importance of quality of school climate and interpersonal relationships in school. Students' perceptions of school climate contribute to their behavioral and emotional adjustment (15). In particular, school climate acts as a protective factor, moderating the effects of certain risk variables (16). Kuperminc et al. (15), for instance, found that a positive school climate buffered the negative effects of self-criticism and lack of self-efficacy on the adjustment of 10-to-14-year-old students. On the contrary low quality of school climate would have a negative impact on students', teachers' and staffs' behavior. In this paper, it aimed to examine the relationship between how school shooting disrupts school climate and what are the consequences of this situation. It is proposed that school climate may cause and trigger delinquent behavior.

\section{MATERIALS and METHODS}

\section{Social Bond Theory}

From the criminological perspective, social environment is one of the key elements for both emergence and prevention of crime. Hirschi's (17) Theory of Social Bond claims that a person's bond to society prevents them from committing crime. The theory is developed by Travis Hirschi in order to understand juvenile delinquency. Theory of Social Bond which is considered as social control theory in criminology was offered in his book "Causes of Deliquency". According to his theory, social bond is formed by four elements: attachment, commitment, involvement and belief. Attachment refers to personal level connection to family, peers, teachers and other people. This emotional status towards others makes us to control our behavior. Another element is commitment which refers to engagement to conventional goals. For instance, if a student has educational goals for future, they will be reluctant to engage in any behaviour that risk their goals. Third element is involvement which refers to how much time spend in conventional activities like hobbies and sports. The idea under this component is that as an individual is too busy doing conventional things, it is harder for them to engage in criminal behavior. Last element is belief which refers to faith to social norms and moral validity of social norms. It is also related to attachment of other people and institution.

Strong social bonds to important social institutions, like family and school, have long been seen as important deterrents of delinquency and crime among adolescents and adults in the criminological literature (18). Through these social bonds, people get attached to conventional values, committed to societal norms, involved in conventional activities, and they come to believe in the moral force behind society's norms. Theory of Social Bond thus explains crime and delinquency as the result of an individual's social bonds being whether weak or nonexistent. Based on this theory, it then makes sense that school attachment, the social bond to one's school, would be important in the etiology of crime and delinquency, especially when it comes to crime and delinquency at school (19).

Pittaro (20) reviewed that school shootings are related with all four elements of social bonding theory which are attachment, commitment, involvement and belief. School shooters mostly show less attachment to their peers. It is also known that most of the school shooters do not have any future goals which mean they lack commitment. Research revealed that school shooters spend most of their times online searching for bomb making strategies and planning attacks (21). So, these students' involvement is mainly on activities related to offending 
behavior. Lastly for the element of belief, it is argued that as the major motivation behind most school shootings is taking revenge, school shooters do not have belief in norms, rules and regulations.

Whereas studies mainly concentrated on reasons behind school shooting and explain it with criminological theories, damage to school safety can harm school climate. Thus, school climate is an important factor in students' academic success, and prosocial behavior, it is important to discuss impact of school shooting in terms of school climate and its effect on students. When highprofile school shootings are specifically examined, there is often an offender at the center with some sort of mental health issue, that issue being whether short-term or long-term. But perhaps this excessive focus on mental health has left the full picture of why school shootings occur unclear. There could be factors related specifically to the school environment that increase negative emotionality and risky behaviors in school (19).

\section{Effects of School Shooting on School Climate}

As school shooting also adversely affect attachment, commitment, involvement and belief of victims, violent acts in school negatively affect students' psychological well-being. Any level of school violence is problematic because it can lead to, beyond the obvious negative consequences like injury and death, a negative learning environment for students (19). Studies reveal that exposure to violence at school is highly related to drop-outs, fear of crime, decreased academic success, trauma related disorders such as PTSD, psychological distress, drug use and delinquency (22). In addition, as school safety diminishes, fear of crime increases (23) and students tend to act out more frequently, even to the degree that they can bring guns to school (24). Moreover, harm to school connectedness can result in mental health problems in students (25) which can result in delinquency and drug use problems. Hence from the social bonding perspective, school shooting can have serious outcomes on students' lives and development.

Victims of a crime can have a higher degree of fear of crime (26). Fear of crime is defined as the feeling of vulnerability to be a victim of a crime even there is no threat (27). As fear of crime is complex phenomenon that has sociological, psychological and criminological dimensions, primary victims of a crime are not the only group that develop fear of crime. Studies showed that fear of crime caused by school shootings effect not only the students at that specific school, but also other students in other schools countrywide (28). Moreover, moral panic (29) and skipping class are highly correlated with fear of crime. Another study proposes that although victimization rates are low, number of students who are afraid of being victimized at school is relatively high (30).

To sum up, school shootings are events that impact not only students and school personnel but also the school climate.
Study results indicate that school climate is an important protective factor against risky behaviours in students.

\section{Effects on School Attachment}

The term school attachment does not have a unique definition; it has been used in the sense of a connection which includes being happy at school and feeling connected to school in an emotional sense (31). According to Blum (32) positive school attachment includes having a sense of belonging and being part of a school, liking school, perceiving that teachers are supportive and caring, having good friends within school, being engaged in their own current and future academic progress, believing that discipline is fair and effective and participating in extracurricular activities (32). Attachment to school is disrupted by violent behavior. Even though there is not sufficient research on school shooting victims' attachment to school environment, there are research on victimization of bullying and other violent behavior in school. Research on bullying reveals that compared to other groups, victims of bullying are the least attached ones to school and that victims' attachment to school is also lower than that of bullies (33). School attachment is also important correlate of aggressive behavior, gun carrying, school achievement, drug use and health problems (32).

Violence and school relation engages the attention of many researchers. Studies conducted on school attachment and violence revealed that both violent behaviors and attitudes toward these behaviors are related with feelings of school attachment. Study on attitudes toward violence shows that a moderate-high degree of school attachment negatively correlates with attitudes toward violence (34). One of the studies found that both school climate and school attachment are related to physical aggression and relational aggression (35). Another study found similar results that school attachment is a predictor of violent-risky behavior like taking part in fights and threatening others (36).

One of the major impacts of school attachment is the one on risky behaviors. Study conducted in South Africa showed that substance abuse, violence related behavior, sexual risk behaviors, and suicidal ideation are related with school attachment (37). Studies found that a low degree of school bonding positively correlated with the use of alcohol and other drugs (38). Although causality link between these two factors remain vague, it is known that there is bidirectional relationship (39). It is important to notice that high level of school bonding have a protective effect on drug and alcohol use (40). Another study revealed that school attachment predicted later substance use, marijuana use and drinking behavior (41). Besides, problematic internet use which is also classified as a risky behavior is correlated with school connectedness (42). Similarly, studies related to deliberate self-harm in adolescence also showed that high school connectedness correlated with reduce risk (43). Risky behaviors related to 
vehicle use like drunk driving (36), suicide ideation and risk of suicide (44), depressive symptoms (45) were also found to be related with school attachment. Depressive symptoms and school attachment both had significant associations with gun carrying at school, and accounting for school attachment reduced the depressive symptoms-gun carrying relationship to insignificance, suggesting they are only related in so far as they are both partially caused by school attachment (19).

To sum up, school attachment is a crucial factor in adolescents' lives as researchers showed that it is correlated with risky behavior, psychological well-being and violent behavior. As studies showed that there is a bidirectional relationship between violence exposure and commission, school shooting can be both the cause and the effect of violent behavior. Besides, it is known that victims of school shooting suffer from mental health problems. School connectedness is a protective factor for mental health of students and risky behaviors which can be result of mental health problems. As school shooting damages the school connectedness level of students, it may lead to other damages in students' lives.

\section{Effects on Commitment}

Another element of social bonding is commitment to conventional goals i. e. having academic goals. According to the social bond theory commitment to educational goals prevents delinquent behavior among students. Study conducted with middle class students supports this view that negative relationship found between commitment and school misconduct (46). A nationwide study conducted in Chile with 21.956 adolescents revealed that school commitment also have effect on smoking behavior. Students with good grades are less likely to engage in smoking behavior (47).

Students' commitment to educational goals is related to various factors including personal background, parental involvement, mathematics ability, school bonding and school climate (46). Students with a higher perception of bullying climate in school are found to be subjects of lower commitment to school (47). Similarly, research showed that being victim of school violence is correlated with lower academic performance (48). Studies found for students who are still enrolled to school after a shooting, their math and English test results were lower than students who transferred into a different school after the event (49). Thus, interaction of school commitment with other factors can result in different or/and more powerful risky behaviors.

\section{Effects on Involvement}

Involvement to school related activities, sports and hobbies is considered as a protective factor against delinquent behavior (50). However, studies showed that facing with violent behavior at school increase students' drop-out rates which means a decrease in students' involvement in school and school related activities (51). Study aimed to figure out school related factors in drop-out rates revealed that students' rate of law violation is positively correlated with rate of school absenteeism (52). As mentioned above, attachment is positively correlated with school involvement and extracurricular activities (53). The outcomes of lower school involvement is still not fully understood as most of the studies focuses on the causes of absenteeism and dropout rates instead of the effects of them. Studies have been conducted on this topic for several years revealed that absenteeism is related to academic achievement, violent behavior, risky behavior and mental health issues (51). One of the studies focused on the effects of absenteeism on students' lives found that low attendance to school cause decreases academic achievement and increases the risk of behavioral problems (54). Not surprisingly, the study found that unexcused absenteeism is found to be related with lower math and reading test scores. Moreover, according to Bridgeland, Bridgeland et al. (55), absenteeism was found to be related to lower academic performance and achievement, fewer literacy skills and grade retention.

Even though causality between school absenteeism and violence is not clear, it is well known that both exposure and commission of violence are related with school absenteeism (56). Victims and perpetrators of violence manifest lower school attendance compared to their school mates (56). Research shows that there is a bidirectional relationship between violence and school attendance especially in terms of school drop-out. Adolescents who drop out of school are more likely to engage in delinquent behavior and correlated with unemployment (57).

As high school drop outs are related to juvenile delinquency and violent behavior, it is also related with other serious problems (58). Especially absenteeism without excuse is correlated with higher rate of engagement in risky behaviors including but not limited to alcohol and drug use, violent behavior and sexual behavior (59). Meta-analysis results also support these results that truancy is one of the best predictors of drug use among youths (60). A longitudinal study showed that drug use and absenteeism have a bi-directional relationship that in some instances, drug use started after school drop-out (57). Besides another longitudinal study found that students with drug problems and high absenteeism have friends who also have problematic behaviors (61). Most of the studies found that truancy is related to mental health issues in children and youths. Study on the effects of absenteeism showed that chronic absentees suffer from internalizing problems that are characterized with feelings of isolation and disengagement (62).

\section{Effects on Belief}

Last element related to school bonding is belief to school norms, regulations and policies. School rules serve to two main aims which are to construct social regulation and foster moral 
socialization. For that reason, school rules are crucial in moral development (63). Although there are studies that are related to morally and socially inappropriate behaviors of the students, there are not many studies which are related to the effects of school norms and rules on these behaviours. According to the social bonding theory, belief and attachment in societal norms and rules is one of the most critical factors that prevent criminal behavior.

School level norms found to be related to substance use, disapproval of substance abuse, and heavy drinking behavior (64). Another study related to school norms and problematic behavior revealed that peer groups' norms and school norms are important components in aggressive behavior. While group norms have direct effects on aggressive behavior, school norms moderate the group norm effect. Authors concluded that especially older children who are more aware of social norms are more likely to act in line with these norms. In other words, school norms not accepting aggressive behavior can be beneficial to provide a decrease in the engagement in aggressive behaviors among students (65).

Besides, studies indicate that students' beliefs regarding to rules are important for adapting them. Students who actively interpret and accept rules are more likely to protect and obey the rules (66). For that reasons rules must be constructed carefully. Studies indicate that belief in the fairness and consistent enforcement of rules are positively related to school commitment, school attendance and negatively related to misconduct behavior. For that reason, school rules are also part of violent behavior of children. Studies show that after a school shooting, school rules could be changed for sake of the students' safety, increased safety measurements did not decrease school violence (24).

\section{DISCUSSION}

School shooting is a concerning violent act which not only impacted students, teachers, families but also terrorize the public. Although most of the studies concentrated on the causes of school shooting, there is little research on effects of school shooting. In light of previous studies, in this paper it is proposed that Hirschi's social bond theory can be used to explain students' risky behaviours and mental health problems after school shootings. According to the social bond theory, a supportive school climate, youths' attachment to school, their involvement in school related activities and their belief in norms are crucial in development of delinquency. Previous studies on students' mental health showed four elements in Social Bond Theory are protective factors against risky behaviours like drug use and school drop-out. For that reasons, school shootings effect on students, school and the interaction between school and students should be examined. Devastating events like school shootings can cause both short term and long term problems in students' lives. In order to protect children and youth from the harmful effects of school shootings, some precautions must be taken.

One of the factors that most of the prevention methods focus on is school attachment. School attachment refers to the relationship between students and school personnel which includes teachers, counselors and administrators. Students who have positive relationships with school personnel are less likely to engage in antisocial acts (67). Volungis and Goodman (68) theorize that teacher-student relationship plays a unique role in the development of school attachment. School counselor is a key person to help teachers to build nonjudgmental, genuine, emphatic relations with their students. Another way to form positive school climate is implementing counseling programs in school (69). Moreover, it is known that increased school attachment has protective effect on risky behaviours. In other words, students with a higher degree of school attachment are less likely to engage in smoking, drinking and delinquent behaviors (70). In line with this research result, a review study on school attachment found that intervention programs aimed to improve school attachment were successful in reducing risky behaviors in students (71).

One of the impacts of school shootings would be on mental health of the students. Studies show that Post-traumatic Stress Disorder (PTSD) is one of the mental health problems that occur as a result of traumatic events. Besides, low school bonding and fear of crime also cause mental health problems like depression, suicidality and emotional distress (72). School shootings can cause severe effects on mental health of students. Therefore, school based programs which are based on both mental health and school climate can be helpful.

Researchers showed that carefully implanted programs which target a certain type of violence and a certain population are successful at reduction of violence (73). Moreover, long term follow-ups of victims for mental health are crucial and can be achieved with the help of the school based mental health personnel (74). A multi-level analysis on school absenteeism and academic achievement showed that these two factors are bi-directionally related with each other, in that positive school climate enhances academic achievement thus decreasing school absenteeism (75).

\section{CONCLUSION}

To conclude, from the criminological perspective of social control theory school shootings can be considered as both the cause and the effect of disrupted school climate. In other words, especially for rampage and targeted school shootings' offenders are motived to take revenge or show their power to the constitution or to the people in that specific constitution which have bullied them. So, disrupted attachment toward 
school can cause violent behavior. In addition, this kind of violent behavior which terrorize whole of the school climate also negatively impact school climate in that students who were victimized are more likely to engage in delinquent behavior, drug use, and criminal behavior in adulthood.

\section{Ethics}

Ethics Committee Approval: Helsinki Declaration rules were followed to conduct this study and no ethical approval is need for this study.

Peer-review: Internally peer-reviewed.

\section{Authorship Contributions}

Concept: A.E., Design: A.E., Data Collection or Processing: A.E., E.I.Ö., Analysis or Interpretation: A.E., E.I.Ö., Literature Search: A.E., E.I.Ö., Writing: A.E., E.I.Ö.

Conflict of Interest: No conflict of interest was declared by the authors.

Financial Disclosure: The authors declared that this study received no financial support.

\section{REFERENCES}

1. Muschert GW. Research in school shootings. Sociol Compass. 2007;1(1):60-80.

2. Böckler N, Seeger T, Sitzer P, Heitmeyer W, (editors). School Shootings. International Research, Case Studies, and Concepts for Prevention. New York, Heidelberg, Dordrecht, London: Springer; 2013.

3. Brockenbrough, KK, Cornell DG, Loper AB. Aggressive attitudes among victims of violence at school. Educ Treat Children. 2002;25(3):273-287.

4. Resnick MD, Ireland M, Borowsky I. Youth violence perpetration: What protects? What predicts? Findings from the National Longitudinal Study of adolescent health. J Adolesc Health. 2004;35(5):424-4e1. https://doi. org/10.1016/j.jadohealth.2004.01.011

5. Beardslee J, Docherty M, Mulvey E, Schubert C, Pardini D. Childhood risk factors associated with adolescent gun carrying among Black and White males: an examination of self-protection, social influence, and antisocial propensity explanations. Law Hum Behav. 2018;42(2):110-118. https://doi. org/10.1037/lhb0000270

6. Borum R, Cornell DG, Modzeleski W, Jimerson SR. What can be done about school shootings? A review of the evidence. Educ Res. 2010;39(1):2737. https://doi.org/10.1002/(SICI)1099-0798(199907/09)17:3<323::AIDBSL349>3.0.CO;2-G

7. Juan SC, Hemenway D. From depression to youth school gun carrying in America: Social connectedness may help break the link. Cogent Social Sciences,2017; 3(1). Published online: 07 Apr 2017https://doi.org/10.1080/ 23311886.2017.1314877

8. Patchin JW, Hinduja S. Traditional and nontraditional bullying among youth: A test of general strain theory. Youth Soc. 2011;43(2):727-751. https:// doi.org/10.1177/0044118x10366951

9. Shetgiri R, Boots DP, Lin H, Cheng TL. Predictors of weapon-related behaviors among African American, Latino, and White youth. J Pediatr. 2016;171:277282. https://doi.org/10.1016/j.jpeds.2015.12.008.

10. Hoy WK, Smith PA, Sweetland SR. The development of the organizational climate index for high schools: Its measure and relationship to faculty trust. High Sch J. 2002;86:38-49.

11. Brand S, Felner RD, Shim MS, Seitsinger A, Dumas T. Middle school improvement and reform: Development and validation of a school-level assessment of climate, cultural pluralism, and school safety. J Educ Psychol. 2003;95:570-588. https://doi.org/10.1037/0022-0663.95.3.570
12. Gottfredson GD, Gottfredson DC, Payne AA, Gottfredson, NC. School climate predictors of school disorder: Results from a national study of delinquency prevention in schools. J Res Crime Delinq. 2005;42:412-444. https://doi. org/10.1177/0022427804271931

13. Bronfenbrenner U. Ecological systems theory. London: Jessica Kingsley Publishers; 1992.

14. Ainsworth MDS, Blehar MC, Waters E, Wall SN. Patterns of attachment: a psychological study of the strange situation. Routledge: Psychology Press; 2015.

15. Kuperminc GP, Leadbeater BJ, Blatt SJ. School social climate and individual differences in vulnerability to psychopathology among middle school students. J Sch Psychol. 2001;39(2):141-159. https://doi.org/10.1016/S00224405(01)00059-0

16. Loukas A, Robinson S Examining the moderating role of perceived school climate in early adolescent adjustment. J Res Adolesc. 2004;14(2):209-233. https://doi.org/10.1111/j.1532-7795.2004.0140x

17. Hirschi T. Causes of delinquency. Routledge: Transaction Publishers; 2002

18. Akers RL, Sellers CS. Criminological theories: introduction, evaluation, and application. 7th ed. New York: Oxford University Press; 2016.

19. Watts SJ, Province K, Toohy K. The kids aren't alright: School attachment, depressive symptoms, and gun carrying at school. Am J Crim Justice. 2019;44(1):146-165. https://doi.org/10.1007/s12103-018-9438-6

20. Pittaro ML. School violence and social control theory: an evaluation of the Columbine massacre. Int J Crim Justice Sci. 2007;2(1):1-12.

21. Vossekuil B, Fein RA, Reddy M, Borum R, Modzeleski W. The final report and findings of the Safe School Initiative. Washington, DC: US Secret Service and Department of Education.2002 Available from: http://pds4.egloos.com/ pds/200704/20/40/ssi_final_report.pdf

22. Popp AM, Peguero AA. Social bonds and the role of school-based victimization. J Interpers Violence. 2012;27(17):3366-3388. https://doi. org/10.1177/0886260512445386

23. Schreck CJ, Miller JM. Sources of fear of crime at school: What is the relative contribution of disorder, individual characteristics, and school security? J Sch Violence. 2003;2(4):57-79. https://doi.org/10.1300/J202v02n04_04

24. Welsh WN. Effects of student and school factors on five measures of school disorder. Justice Q. 2001:18(4):911-947. https://doi. org/10.1080/07418820100095131

25. Shochet IM, Dadds MR, Ham D, Montague, R. School connectedness is an underemphasized parameter in adolescent mental health: Results of a community prediction study. J Clin Child Adolesc Psychol. 2006;35(2):170179. https://doi.org/10.1207/s15374424jccp3502_1

26. Bachman R, Randolph A, Brown BL. Predicting perceptions of fear at school and going to and from school for African American and White students: The effects of school security measures. Youth Soc. 2011;43(2):705-726. https:// doi.org/10.1177/0044118X10366674

27. Rader N. Fear of crime. Oxford: Oxford Research Encyclopedia of Criminology and Criminal Justice; 2017 https://doi.org/10.1093/ acrefore/9780190264079.013.10

28. Kaminski RJ, Koons-Witt BA, Thompson NS, Weiss D. The impacts of the Virginia Tech and Northern Illinois University shootings on fear of crime on campus. J Crim Justice. 2010;38(1):88-98. https://doi.org/10.1016/j. jcrimjus.2009.11.011

29. Schildkraut J, Elsass HJ, Stafford MC. Could it happen here? Moral panic, school shootings, and fear of crime among college students. Crime, Law Soc Chang. 20156;63(1-2):91-110. https://doi.org/10.1007/s10611-015-9552-z

30. Snell C, Bailey C, Carona A, Mebane D. School crime policy changes: The impact of recent highly-publicized school crimes. Am J Crim Justice. 2002;26(2):269-285. https://doi.org/10.1007/BF02887831

31. Libbey HP. Measuring student relationships to school: attachment, bonding, connectedness, and engagement. J Sch Health. 2004;74(7):274-283. https:// doi.org/10.1111/j.1746-1561.2004.tb08284.x 
32. Blum R. School connectedness: Improving students' lives. Military Child Initiative, 1-18. 2005. Available from: https://www.dshs.state. tx.us/schoolhealth/tshac/School_Connectedness_Improving_Students_ Lives_2007.pdf

33. Cunningham NJ. Level of bonding to school and perception of the school environment by bullies, victims, and bully victims. J Early Adolesc. 2007;27(4):457-478. https://doi.org/10.1177/0272431607302940

34. Chung-Do JJ, Goebert DA, Hamagani F, Chang JY, Hishinuma ES. Understanding the role of school connectedness and its association with violent attitudes and behaviors among an ethnically diverse sample of youth. J Interpers Violence. 2017;32(9):1421-1446. https://doi.org/10.1177/0886260515588923

35. Wilson D. The interface of school climate and school connectedness and relationships with aggression and victimization. J Sch Health. 2004;74(7):293299. https://doi.org/10.1111/j.1746-1561.2004.tb08286.x

36. Chapman RL, Buckley L, Sheehan MC, Shochet IM, Romaniuk M. The impact of school connectedness on violent behavior, transport risk-taking behavior, and associated injuries in adolescence. J Sch Psychol. 2011;49(4):399-410. https://doi.org/10.1016/j.jsp.2011.04.004

37. Govender K, Naicker SN, Meyer-Weitz A, Fanner J, Naidoo A, Penfold WL. Associations between perceptions of school connectedness and adolescent health risk behaviors in South African high school learners. J Sch Health. 2013;83(9):614-622. https://doi.org/10.1111/josh.12073

38. Bryant AL, Schulenberg JE, O’Malley PM, Bachman JG, Johnston LD. How academic achievement, attitudes, and behaviors relate to the course of substance use during adolescence: A 6-year, multiwave national longitudinal study. J Res Adolesc. 2003;13(3):361-397. https://doi.org/10.1111/15327795.1303005

39. Bachman JG, Schulenberg JE, Freedman-Doan P, O'Malley PM, Johnston LD, Messersmith EE. The education-drug use connection: how successes and failures in school relate to adolescent smoking, drinking, drug use, and delinquency. Routledge: Psychology Press; 2008.

40. Desousa C, Murphy S, Roberts C, Anderson L. School policies and binge drinking behaviours of school-aged children in Wales-a multilevel analysis. Health Educ Res. 2008;23(2):259-271. https://doi.org/10.1093/her/cym030

41. Bond L, Butler H, Thomas L, Carlin J, Glover S, Bowes G, et al. Social and school connectedness in early secondary school as predictors of late teenage substance use, mental health, and academic outcomes. J Adolesc Health. 2007;40(4):357-e9-18. https://doi.org/10.1016/j.jadohealth.2006.10.013

42. Li D, LiX, Wang Y, Zhao L, Bao Z, Wen F. School connectedness and problematic Internet use in adolescents: A moderated mediation model of deviant peer affiliation and self-control. J Abnorm Child Psychol. 2013;41(8):1231-1242. https://doi.org/10.1007/s10802-013-9761-9

43. Stallard P, Spears M, Montgomery AA, Phillips R, Sayal K. Self-harm in young adolescents (12-16 years): onset and short-term continuation in a community sample. BMC Psychiatry. 2013;13(1):328. https://doi. org/10.1186/1471-244X-13-328

44. Marraccini ME, Brier ZM. School connectedness and suicidal thoughts and behaviors: A systematic meta-analysis. Sch Psychol Q. 2017;32(1):5-21. https://doi.org/10.1037/spq0000192

45. Shochet IM, Homel R, Cockshaw WD, Montgomery DT. How do school connectedness and attachment to parents interrelate in predicting adolescent depressive symptoms? J Clin Child Adolesc Psychol. 2008;37(3):676-681. https://doi.org/10.1080/15374410802148053

46. Jenkins $\mathrm{PH}$. School delinquency and school commitment. Soc Educ. 1995;68:221-239.

47. Mehta SB, Cornell D, Fan X, Gregory A. Bullying climate and school engagement in ninth-grade students. J Sch Health. 2013;83(1):45-52. https:// doi.org/10.1111/j.1746-1561.2012.00746.x

48. Juvonen J, Wang Y, Espinoza G. Bullying experiences and compromised academic performance across middle school grades. J Early Adolesc. 2011;31(1):152-173. https://doi.org/10.1177/0272431610379415
49. Beland LP, Kim D. The effect of high school shootings on schools and student performance. Educ Eval Policy Anal. 2006;38(1):113-126. https:// doi.org/10.3102/0162373715590683

50. Burton JM, Marshall LA. Protective factors for youth considered at risk of criminal behaviour: does participation in extracurricular activities help? Crim Behav Ment Health. 2005;15(1):46-64. https://doi.org/10.1002/ cbm.36

51. Brookmeyer KA, Fanti KA, Henrich CC. Schools, parents, and youth violence: a multilevel, ecological analysis. J Clin Child Adolesc Psychol. 2006;35(4):504514. https://doi.org/10.1207/s15374424jccp3504_2

52. Christle CA, Jolivette K, Nelson CM. School characteristics related to high school dropout rates. Remedial Spec Educ. 2007;28(6):325-339. https://doi. org/10.1177/07419325070280060201

53. Martinez A, Coker C, McMahon SD, Cohen J, Thapa A. Involvement in extracurricular activities: identifying differences in perceptions of school climate. European Psychiatry. 2016;33(1):70-84. https://doi.org/10.1017/ edp. 2016.7

54. Gottfried MA. Excused versus unexcused: How student absences in elementary school affect academic achievement. Educ Eval Policy Anal. 2009;31(4):392-415. https://doi.org/10.3102/0162373709342467

55. Bridgeland JM, Dilulio JJ, Morison KB. The silent epidemic: Perceptions of high school dropouts. 2006. Available from: https://files.eric.ed.gov/fulltext/ ED513444.pdf

56. Ramirez M, Wu Y, Kataoka, S, Wong M, Yang J, Peek-Asa C, et al. Youth violence across multiple dimensions: a study of violence, absenteeism, and suspensions among middle school children. J Pediatr. 2012;161(3):542-546. https://doi.org/10.1016/j.jpeds.2012.03.014

57. Cook PJ, Kang S. Birthdays, schooling, and crime: Regression-discontinuity analysis of school performance, delinquency, dropout, and crime initiation. Am Econ J Appl Econ. 2016;8(1):33-57. https://doi.org/10.1257/app.20140323

58. Neely P, Griffin-Williams A. High school dropouts contribute to juvenile delinquency. Rev High Ed Selflearning. 2013;6(22):88-119. https://doi. org/10.1111/j.1751-9020.2007.00008.x

59. Eaton DK, Brener N, Kann LK. Associations of health risk behaviors with school absenteeism. Does having permission for the absence make a difference? J Sch Health. 2008;78(4):223-229. https://doi.org/10.1111/j.17461561.2008.00290.x

60. Hallfors D, Vevea JL, Iritani B, Cho H, Khatapoush S, Saxe L. Truancy, grade point average, and sexual activity: A meta-analysis of risk indicators for youth substance use. J Sch Health. 2002;72(5):205-211. https://doi. org/10.1111/j.1746-1561.2002.tb06548.x

61. Wichstrøm L. Alcohol intoxication and school dropout. Drug Alcohol Rev. 1998;17(4):413-421. https://doi.org/10.1080/09595239800187251

62. Gottfried, MA. Chronic absenteeism and its effects on students' academic and socioemotional outcomes. J Educ Stud Placed Risk. 2014;19(2): 53-75. https://doi.org/10.1080/10824669.2014.962696

63. Thornberg R. The moral construction of the good pupil embedded in school rules. Educ Citizsh Soc Justice. 2009;4(3):245-261. https://doi. org/10.1177/1746197909340874

64. Kumar R, O'Malley PM, Johnston LD, Schulenberg JE, Bachman JG. Effects of school-level norms on student substance use. Prev Sci. 2002;3(2):105-124. https://doi.org/10.1023/A:1015431300471

65. Nipedal C, Nesdale D, Killen M. Social group norms, school norms, and children's aggressive intentions. Aggress Behav. 2010;36(3):195-204. https:// doi.org/10.1002/ab.20342

66. Thornberg R. 'It's not fair!'-voicing pupils' criticisms of school rules. Child Soc. 2008;22(6):418-428. https://doi.org/10.1111/j.1099-0860.2007.00121.x

67. Karcher MJ. Connectedness and school violence: a framework for developmental interventions. In: Handbook of school violence and school safety, Routledge; 2004. pp. 7-42. 
68. Volungis AM, Goodman K. School violence prevention: Teachers establishing relationships with students using counseling strategies. SAGE Open. 2017;7(1):1-11. https://doi.org/10.1177/2158244017700460

69. Lapan RT, Gysbers NC, Sun Y. The impact of more fully implemented guidance programs on the school experiences of high school students: A statewide evaluation study. J Couns Dev. 1997;75(4):292-302. https://doi. org/10.1002/j.1556-6676.1997.tb02344.x

70. Dornbusch SM, Erickson KG, Laird J, Wong CA. The relation of family and school attachment to adolescent deviance in diverse groups and communities. J Adolesc Res. 2001;16(4):396-422. https://doi. org/10.1177/0743558401164006

71. Chapman RL, Buckley L, Sheehan M, Shochet I. School-based programs for increasing connectedness and reducing risk behavior: a systematic review. Educ Psychol Rev. 2013;25(1):95-114. https://doi.org/10.1007/s10648-0139216-4
72. Stafford M, Chandola T, Marmot M. Association between fear of crime and mental health and physical functioning. Am J Public Health. 2007;97(11):2076-2081. https://doi.org/10.2105/AJPH.2006.097154

73. Farrell AD, Meyer AL, Kung EM, Sullivan TN. Development and evaluation of school-based violence prevention programs. J Clin Child Psychol. 2001;30(2):207-220. https://doi.org/10.1207/\$15374424JCCP3002_8

74. Crepeau-Hobson F, Sievering KS, Armstrong C, Stonis J. A coordinated mental health crisis response: lessons learned from three Colorado school shootings. J Sch Violence. 2012;11(3):207-225. https://doi.org/10.1080/15388220.2012. 682002

75. Smyth E. Pupil performance, absenteeism and school drop-out: a multidimensional analysis. Sch Eff Sch Improv. 1999;10(4):480-502. https://doi. org/10.1076\%2Fsesi.10.4.480.3496 